\title{
Long-term dynamics of mouse-like rodents population size in dark coniferous forest of the East Sayan mountains
}

\begin{abstract}
Vladislav V. Vinogradov
ABSTRACT. Long-term dynamics of small mammals communities from dark coniferous forests of the East Sayan was studied for a period of 26 years. The study was conducted in the natural reserve «Stolby» and the adjacent areas. The analysis of the long-term dynamics has shown that various species population size fluctuations phases do not coincide. It results in the changes of structure of dominance with the leading position taken by northern red-backed vole (Myodes rutilus) and gray red-backed vole (Myodes rufocanus). The duration of the population cycle varies in different species from two to four years. In general, the community is characterized by clear harmonic fluctuations with a four-year amplitude. Unidirectional irreversible changes in population in this community do not exist, that in general characterizes it as stable and sustainable. The leading impact on the population size in the studied group of species is caused by the total summer temperature and the rainfalls. These factors control fluctuations of the small mammals numbers in the range of $31-56 \%$. In addition, the influence of seed productivity as well as predators' (smaller mustelids) pressure should not be underestimated.
\end{abstract}

KEY WORDS: mouse-like rodents, long-term population size dynamics, environmental factors.

VladislavV. Vinogradov [vlad-vin@yandex.ru], V.P. Astafiev Krasnoyarsk Pedagogical University, A. Lebedeva street 89, Krasnoyarsk 660049, Russia

\section{Многолетняя динамика численности мышевидных грызунов темнохвойной тайги Восточного Саяна}

\section{В.В. Виноградов}

РЕЗЮМЕ. Рассмотрена многолетняя динамика сообщества мышевидных грызунов темнохвойной тайги Восточного Саяна в течение 26 лет. Работы проведены на территории заповедника «Столбы» и прилегающих участках. Анализ многолетней динамики численности показал, что фазы колебаний численности разных видов не совпадают, и поэтому структура доминирования сообщества меняется, при этом ведущая роль принадлежит красной (Myodes rutilus) и красно-серой (Myodes rufocanus) полевкам. Продолжительность циклических изменений у разных видов колеблется от 2 до 4 лет. В целом сообщество имеет хорошо выраженные гармонические колебания с амплитудой 4 года. Однонаправленные необратимые изменения численности в данном сообществе отсутствуют, что в целом характеризует его как стабильное и устойчивое. С помощью метода множественной пошаговой регрессии установлено, что определяющее влияние на динамику численности рассматриваемой группы животных оказывают суммарная температура летнего периода и сумма осадков, которые определяют колебания численности на 31-56\%. Кроме того высока значимость урожайности семян древесных пород и пресс хищников (мелких куньих).

КЛЮЧЕВЫЕ СЛОВА: мышевидные грызуны, динамика численности, факторы среды.

\section{Introduction}

One of the urgent problems of modern ecology is the study of the organization and dynamics of communities of terrestrial vertebrates (Dzhiller, 1988; Hörnfeldt, 2004, Korpimaki et al., 2005, Litvinov et al., 2007). Long-term monitoring of abundance, both of single populations and whole communities permits a better understanding if faunal changes under the influence of various external factors. Rodents are the suit- able model group for such kind of researches. It is a large group of vertebrates, characterized by high abundance, well-defined population cycles and high sensitivity to any habitat changes.

In this study we attempt to analyze materials obtained from long-term monitoring of small mammals in the State nature Reserve "Stolby" and adjacent territory. The study was conducted in typical parts of the mountain dark coniferous forest of the East Sayan. The animal census was accompanied by recording of main 


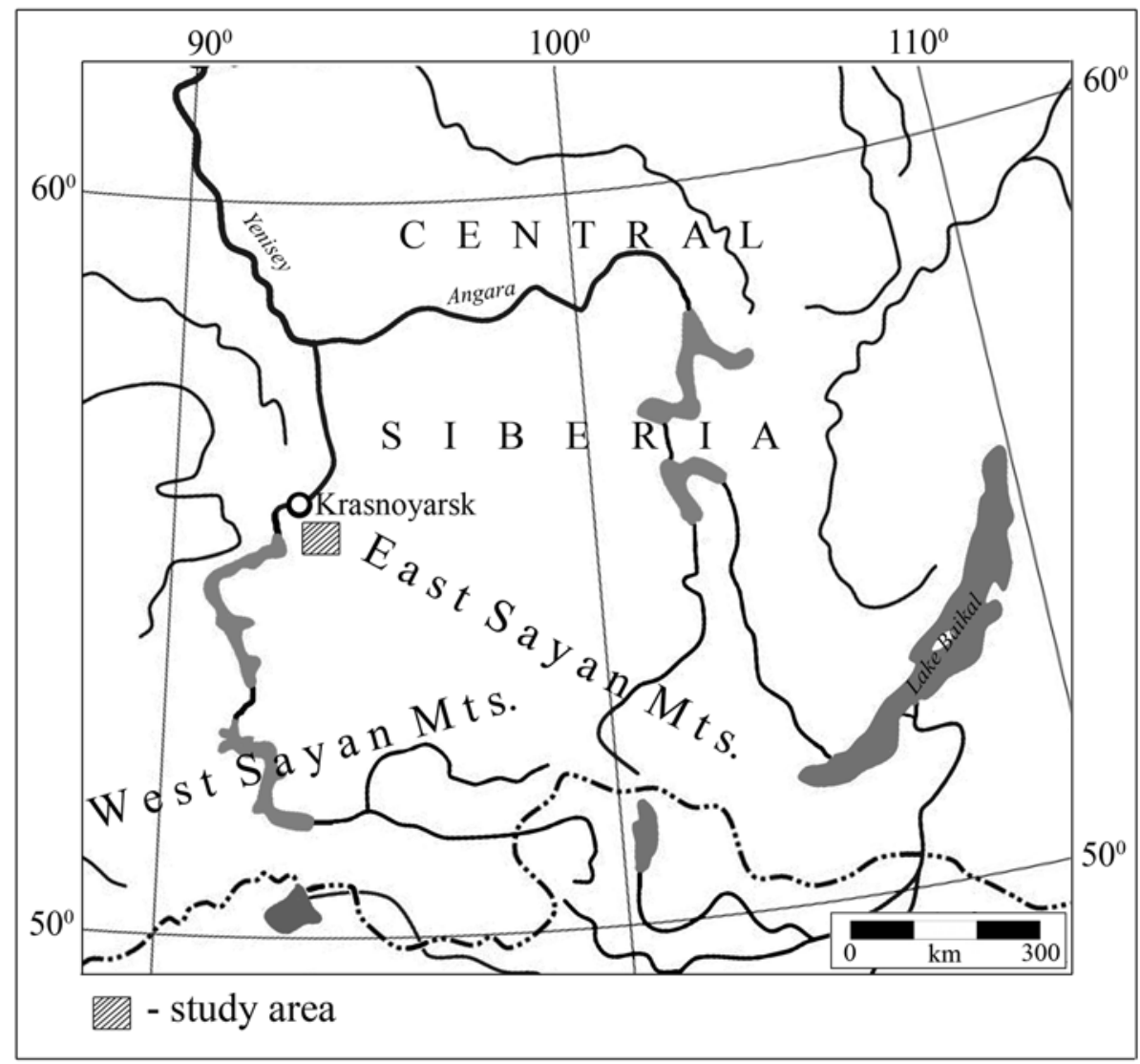

Figure 1. Study area.

climatic parameters, seed yield and predators (small mustelids) numbers. The main objectives included determination of the community structure in different years, clarifying the duration of cyclical abundance fluctuations for individual species and the community as a whole, identifying of general trends in these values, and calculation of the dependence of the numerical characteristics from various external factors.

\section{Material and methods}

The materials were collected in the period from 1981-1989, 1992-1997, and 1999-2009. In different time period, the work was performed by V. Bulavkin, A. Zyryanov, A. Khritankov, B. Kelbeshekov, and V. Vinogradov. All materials were collected and processed with the use of uniform methods. Single annual captures of animals were conducted by the standard method of ditch trapping (50 $\mathrm{m}$ in length with five cones) in the same time period, between July 20 and August 20, during the peak of abundance of small mammals in boreal forests (Schwartz et al., 1992; Rexstad \& Debevec, 2006; Ravkin \& Lebanon, 2008).

The index of relative number, namely the number of individuals calculated for 100 conventional cones per day (c/d), as well as the index of dominance, which is a percentage of the species in the catch (Beklemishev,
1961), were used for the quantitative characteristics of species in the community.

The total number of $\mathrm{c} / \mathrm{d}$ is 7080 . The data on population dynamics of eight species of rodents was analyzed. The studied material includes 3257 individuals.

The studies were conducted in key sites covered by dark coniferous forest with predominance of Siberian fir in the altitude range of 450-650 $\mathrm{m}$ above sea level. Coordinates of the survey area are $55^{\circ} 48^{\prime} 39^{\prime \prime}-55^{\circ}$ $54^{\prime} 24^{\prime \prime}$ N, $92^{\circ} 42^{\prime} 28^{\prime \prime}-93^{\circ} 01^{\prime} 23^{\prime \prime}$ E (Fig. 1).

Data on long-term population dynamics of small rodents are presented as graphs. Abundance of species is divided into the following classes: dominant $-10<\mathrm{n}$ $<100$; normal (common) $-1<\mathrm{n}<10$; rare $-0,1<\mathrm{n}$ $<1$ (Litvinov \& Pozhidaeva, 2008).

The similarity degree of population dynamics of species was determined using cluster analysis by Unweighted Pair Group Method with Arithmetic Mean (Puzachenko, 2004) based on the correlation matrix. The correlation between species was calculated using Pearson correlation coefficient (Puzachenko, 2004).

We used spectral analysis to determine a regular component in the time series for each species and within the community. Periodograms, which show the duration of regular harmonic oscillations of the populations in the form of dispersion peaks, were built based on the last data. The maximum variance value directly indicates the duration of the harmonic oscillation of each 
species during the period under review (Puzachenko, 2004). Statistical significance of each maximum variance value was determined by the Fisher criterion (Ftest) and the coefficient of determination $\left(\mathrm{R}^{2}\right)$. The paper presents the periodograms for only four species of rodents, in which the maximum values of the periodogram, showing the average duration of cyclic changes, was statistically significant.

In order to determine the duration of cyclic changes within the whole community, values of the total number of rodents during the entire observation period were analyzed using spectral analysis with the determination of the spectral density peak. Spectrum was constructing using the Hamming window method of 10 years. This procedure assigns the greatest weight to the observation being smoothed in the center of the window, and increasingly smaller weights to values which are further away from the center (Puzachenko, 2004).

The selection of the regular component of harmonic oscillations of the whole community was followed by the examination of the time series of the total number of rodents for the presence of continuing noncyclical changes. For this purpose the analysis of residues obtained during removing of identified cyclic trend with a decreasing autocorrelation function was conducted.

We applied the method of principal components for ordination of annual species abundance and identification of internal factors determining the dynamics and community structure. Data matrix icluded the values of the relative population size of rodent species (years objects, species - features). To provide a visual display of the ordination results, we built a scatterplot connecting points with dotted lines (splines) (Litvinov et al, 2007).

A multiple regression model based on various external factors was calculated for each species (Schnurr et al., 2004; Rexstad \& Debevec, 2006; Milstead et al., 2007; Andreeva \& Okulova, 2009). Two species, wood lemming and bank vole, were excluded from analisys due to extremely low population size and large time gaps in data, when the species were absent in captures during several seasons. The following features were used as variables: the sum of temperatures for January, April, May and the summer period, the sum of precipitation during the summer and the year; the maximum snow depth, the total yield of seeds of coniferous trees (pine, fir, spruce) on a scale from 0.5 to 5.0 ; the total relative abundance (calculated counting traces per 10 $\mathrm{km}$ of the route in January-February) of small mustelids (sable, Siberian weasel, least weasel). The data was obtained from the annual scientific reports of the Reserve «Stolby», personal materials of the author and the reports of the meteorological service «Narym» located on the territory of the reserve. Calculations were carried out in several stages by multiple stepwise regression (Lima et al., 2002; Puzachenko, 2004):

1. Particular regression models $\left(y=a+b_{i} X_{i}\right)$ were calculated. The quality of each model was determined using F-test.
2. The threshold value F, which limited the inclusion of a variable into the model, was determined.

3. A particular regression model with maximum Fvalue was selected, as a consequence the next variable with the second F-value was added to the model and parameters of the new model were recalculated. The option with a higher F-value was accepted. The range of F-values was $0.50-1.00$.

All calculations were made in «Cluster analysis», «Factor Analysis» and «Multiple regression» modules of Statistica 6.0.

\section{Results}

\section{Composition, Dynamics and Structure of Community Dominance}

Rodent community of dark coniferous taiga of East Sayan includes eight species. Northern red-backed vole (Myodes rutilus Pallas, 1811) and gray red-backed vole (Myodes rufocanus Pallas, 1811) predominate in the community. Ordinary (common) species include root vole (Microtus oeconomus Pallas, 1776), Eastern-Asian mouse (Apodemus peninsulae Thomas, 1907), northern birch mouse (Sicista betulina Pallas, 1779) and field vole (Microtus agrestis L., 1761). Rare species in the community are wood lemming (Myopus schisticolor Lilljeborg, 1844) and the bank vole (Myodes glareolus Pallas, 1811). This set of species is characteristic of the greater part of the mountainous forests areas in the Altai-Sayan mountain country, and it does not change from the forest-steppe foothills to subalpine woodlands throughout the East Sayan from the Yenisei River to Baikal Lake (Yudin et al., 1979).

Despite the relative stability of species composition, the total abundance changes significantly during the period under review (Fig. 2).

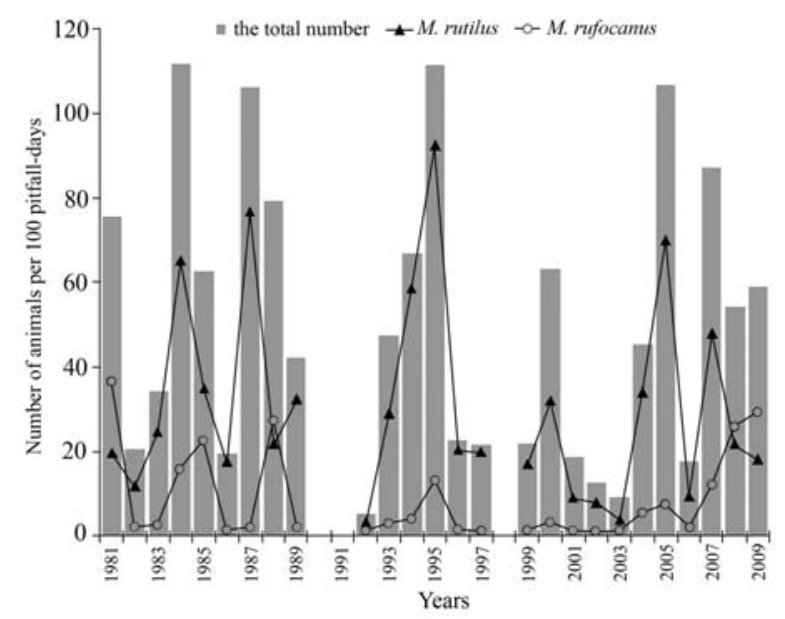

Figure 2. Long-term dynamics of the total number of community and dominant species of rodents of dark coniferous forest of East Sayan. 


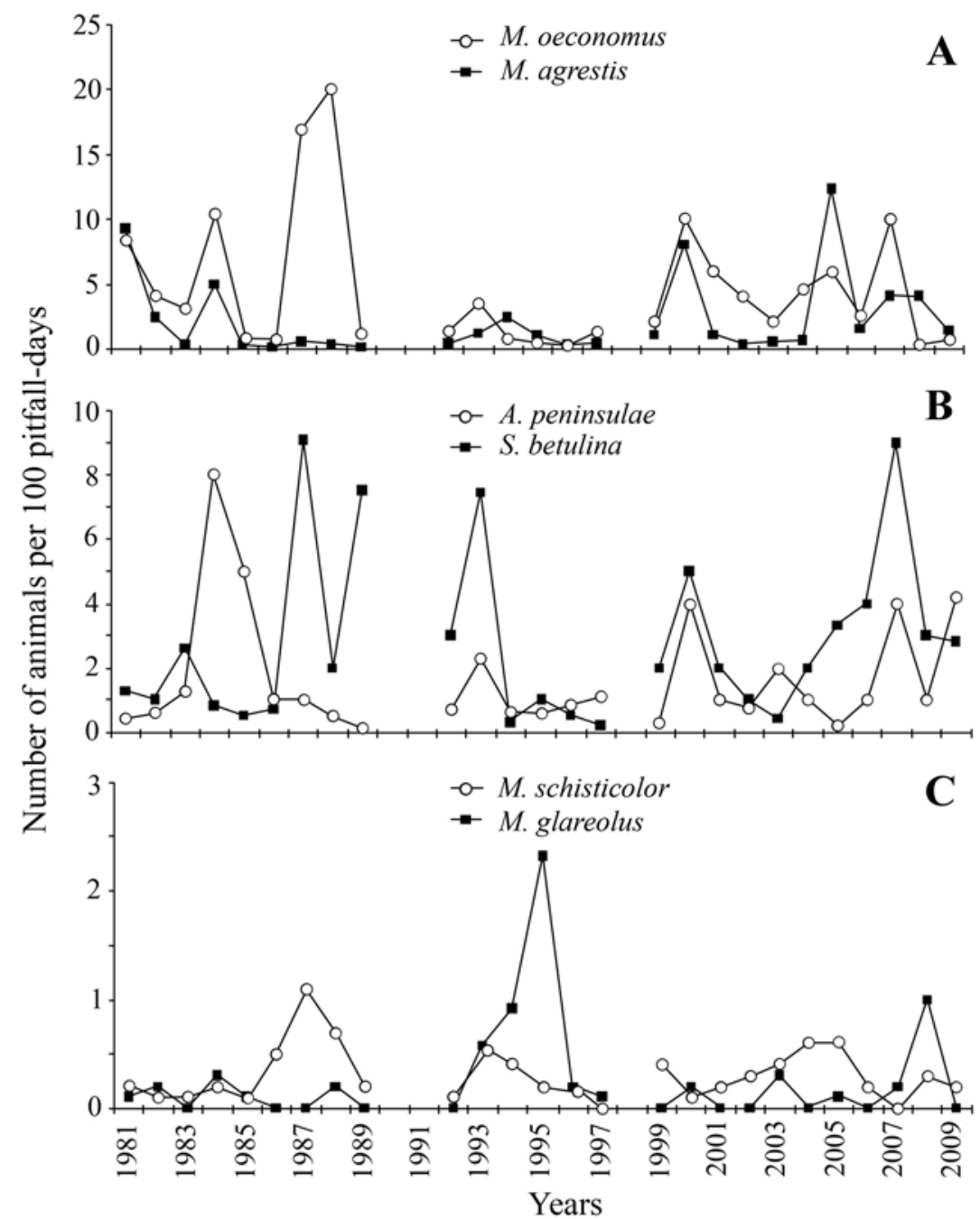

Figure 3. Long-term dynamics of the number of common (A, B) and rare (C) species of rodents of dark coniferous forest of East Sayan.

A comparison of the long-term population dynamics of rodents, allows regarding 1982, 1983, 1993, 1994, 2004 and 2008 as the ascending phase of population; 1981, 1984, 1987, 1995, 2000, 2005, 2007 - as a peak phase; 1985, 1988, 1996, 2001 - as a phase of decline; 1982, 1986, 1992, 1997, 2002, 2003 and 2006 as a phase of the number depression. The maximum value of the total number was observed in 1995 112.3 individuals per $100 \mathrm{c} / \mathrm{d}$. The minimum value recorded in 1992 was 9.4 individuals per $100 \mathrm{c} / \mathrm{d}$, which indicates a 12-times change of this index over the 26-year observation period.

The dominant species - northern red-backed vole and gray red-backed vole make the basic part of the community. The total share of dominant species varies from 51.5 to $94.8 \%$. The number of northern red-backed vole varies considerably from year to year, with obvious peaks and declines from 4.0 to 92.5 individuals per $100 \mathrm{c} / \mathrm{d}$, whereby the share varies from 25.8 to $83.5 \%$.
In case of gray red-backed vole fluctuation amplitude reaches high values. Its share varies within $2.1-51.8 \%$, which makes almost a 25-times change, and the number varies from 0.5 to 36.4 individuals per $100 \mathrm{c} / \mathrm{d}$.

Common species fraction is characterized by more stable indices and ranges from 7.4 to $57.4 \%$. This amplitude determines more than a 7-times change in the number of species in this group (Fig. 3).

Among the common species root vole is characterized by the highest average index of dominance (10.2\%). Hereby the species population size varies from 1.0 to 19.8 individuals per $100 \mathrm{c} / \mathrm{d}$. In case of a smaller northern birch mouse similar figures make 7\% and 0.5-7.4 individuals per $100 \mathrm{c} / \mathrm{d}$, the eastern asian mouse $4.2 \%$ and $0.2-4.2$ individuals per $100 \mathrm{c} / \mathrm{d}$, the field vole - 4\%, and 0.1-12.3 individuals per $100 \mathrm{c} / \mathrm{d}$.

Rare species: wood lemming and the bank vole, have sporadic distribution in the area under study, are not present in the catch every year, and, as a rule, in 


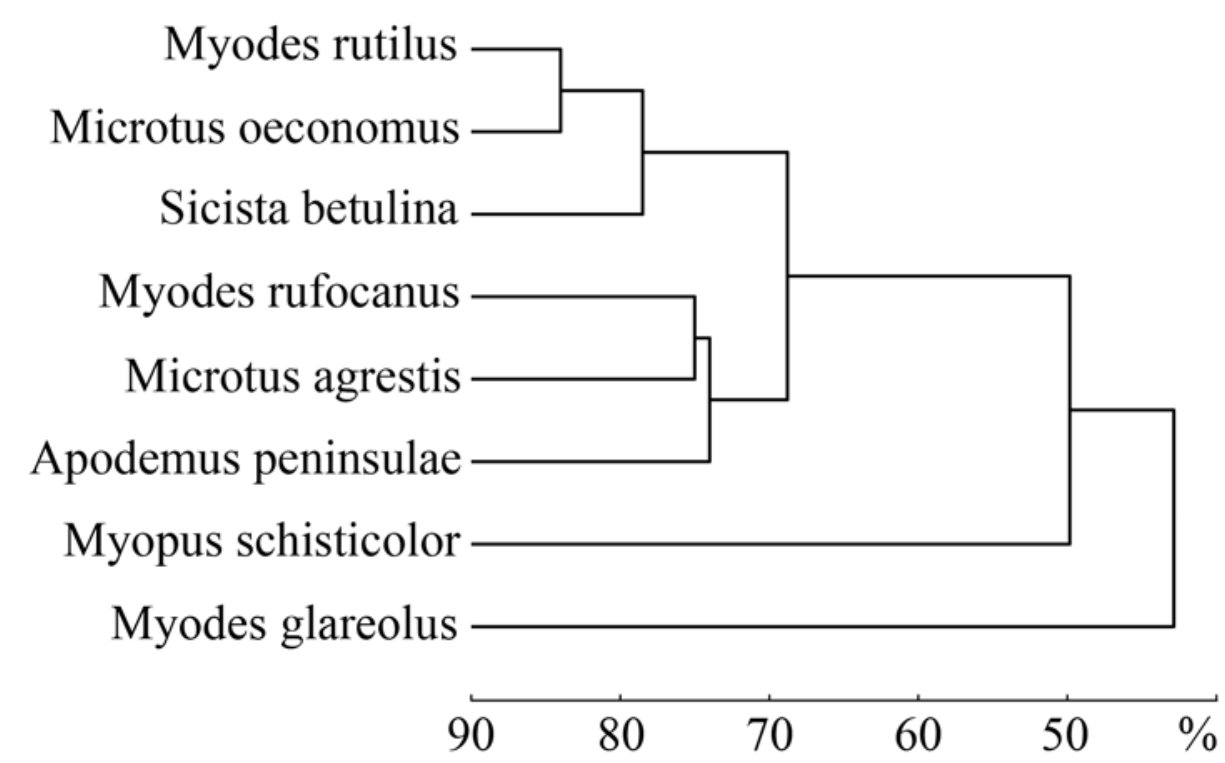

Figure 4. Dendrogram of similarities of long-term population dynamics of rodents of dark coniferous forest of East Sayan.

single specimens. Their number varies from 0.1 to 2.5 individuals per $100 \mathrm{c} / \mathrm{d}$, while the total equity participation does not exceed $6 \%$. In some years, during the period under review, there have been slight rises in their abundance (see Fig. 3, C).

Calculation of degree of similarity between longterm dynamics of different rodent species shows the internal heterogeneity of the community on this basis (Fig. 4).

All species are divided into two clusters and two ungrouped species in the dendrogram.

For a detailed identification of parameters underlying the long-term fluctuations in the number of mouselike rodents we should trace the structure of time series.

Investigations of the structural organization of the time series

The results of spectral analysis of long-term population dynamics of 4 species of rodents are presented as periodogram (Fig. 5).

The maximum values of the variance for all species and the evaluation of their statistical significance are presented in the table (Tab. 1).

The longest duration of the cycle is observed in case of northern red-backed vole and gray red-backed vole. A shorter cycle is characteristic of root vole. The shortest cycle is observed in case of northern birch mouse.

The results of the analysis of cyclic changes in the community of rodents are shown in Fig. 6.

The graph shows that the greatest power of fluctuations falls on to a period of 4 years. The evaluation of the statistical significance of the results demonstrated a high degree of reliability $(\mathrm{F}=164.3 ; \mathrm{p}<0,0001)$.
An analysis of residues obtained by removing the identified trend by means of decreasing autocorrelation function is shown in Figure 7. The values of correlation for each time lag are presented as columns. The values of the autocorrelation function do not exceed the boundaries of the confidence interval. High positive correlation values are observed at $20 \mathrm{lag}$, where it comes into contact with the confidence interval.

The results of principal components analysis is shown in Fig. 8. The first and second principal components explain $93.1 \%$ of total variance. $1 \mathrm{PC}$ has a negative correlation $(-0.34)$ with the abundance of northern redbacked vole, and a positive correlation $(0.78)$ with the abundance of gray red-backed vole. 2 PC has a strong positive correlation (0.96) with the abundance of gray red-backed vole, and there are no correlations with northern red-backed vole $(-0.06)$.

\section{Multivariate regression models construction}

Multiple regression models were constructed for every species to determine the leading environmental factors affecting rodent numbers during the period under review. Parameters of models are tabulated (Table 2).

\section{Discussion}

The dynamics and structure of rodent community was studied for the four cycles: the population number increasing phase, the phase of decline, the phase of depression, and the maximum numbers phase. Longterm amplitude of fluctuations in the number of different species is characterized by significant differences. The highest numbers are characteristic for the gray red- 

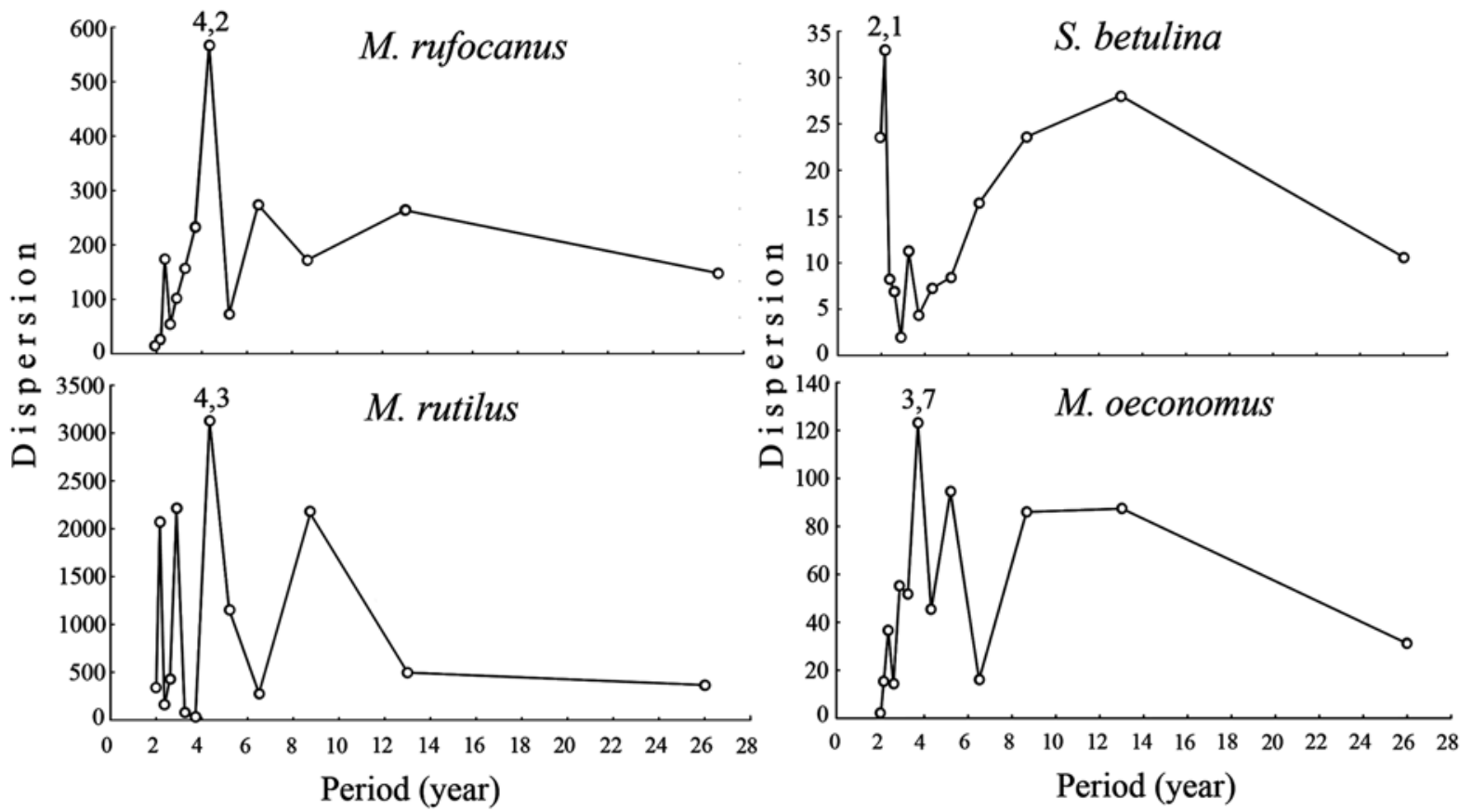

Figure 5. Periodogram of long-term dynamics of 4 species of rodents of dark coniferous forest of East Sayan.

Table 1. Evaluation of statistical significance of the duration of period of fluctuations in the number of maxima dispersion of long-term population dynamics of rodents of dark coniferous forests of the East Sayan (1981-2009).

\begin{tabular}{|l|l|l|l|l|}
\hline Species & Period & $F$ & $p$-level & $R^{2}$ \\
\hline M. rutilus & 4.3 & 10.72 & 0.016 & 0.570 \\
M. rufocanus & 4.2 & 7.78 & 0.023 & 0.420 \\
M. oeconomus & 3.7 & 11.63 & 0.019 & 0.528 \\
S. betulina & 2.1 & 7.65 & 0.017 & 0.390 \\
A. peninsulae & 3.2 & 4.18 & 0.152 & 0.270 \\
M. agrestis & 2.6 & 0.25 & 0.637 & 0.148 \\
M. schisticolor & 4.8 & 0.59 & 0.484 & 0.161 \\
M. glareolus & 4.6 & 0.18 & 0.577 & 0.083 \\
\hline
\end{tabular}

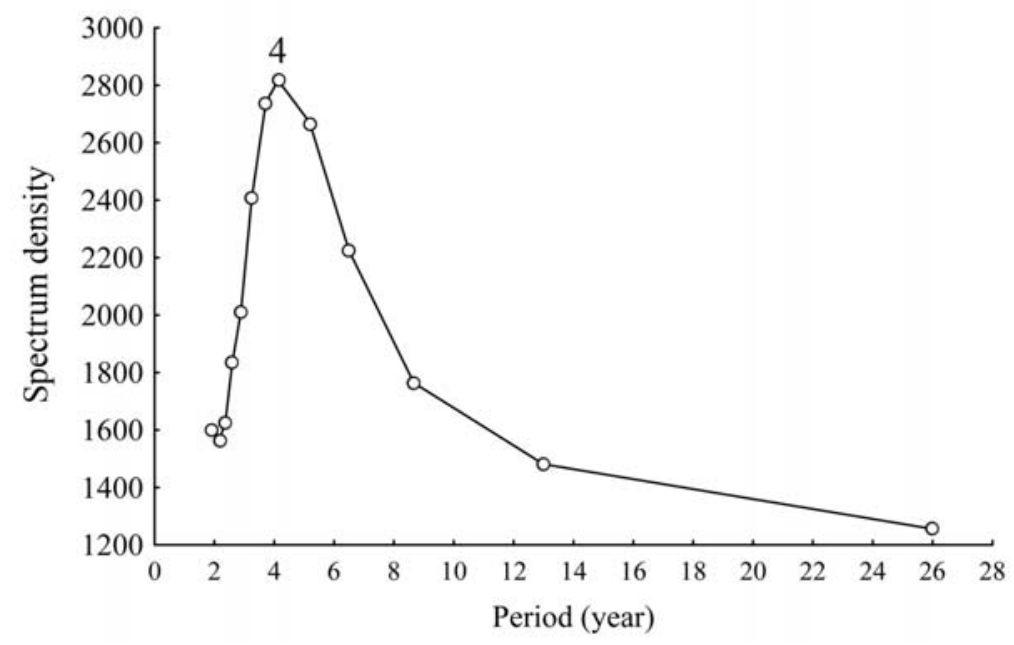

Figure 6. Spectral density of the number of values of a total long-term number of rodents community of dark coniferous forest of East Sayan. 


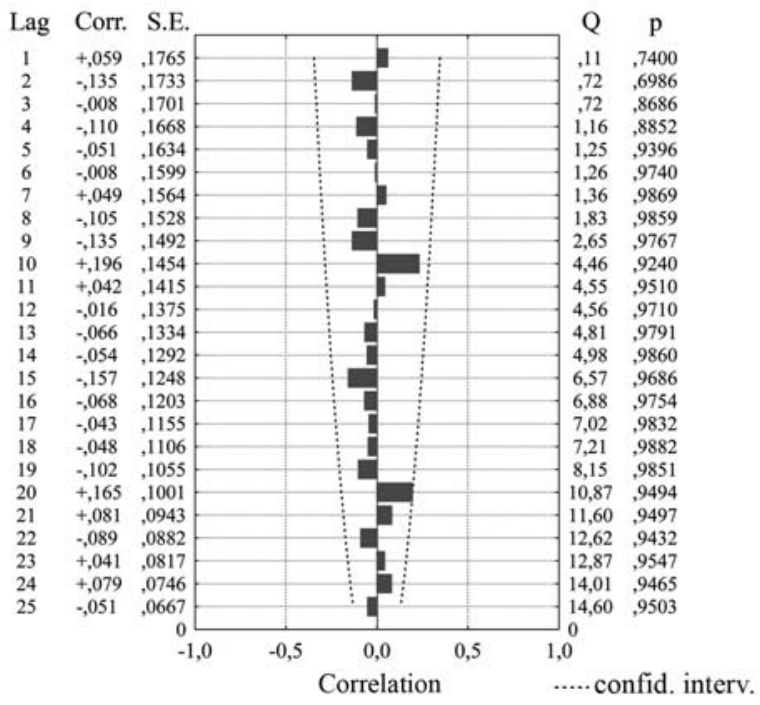

Figure 7. Autocorrelation function of residues of the set of total number of rodents community from dark coniferous forest of East Sayan for the period from 1981 to 2009.

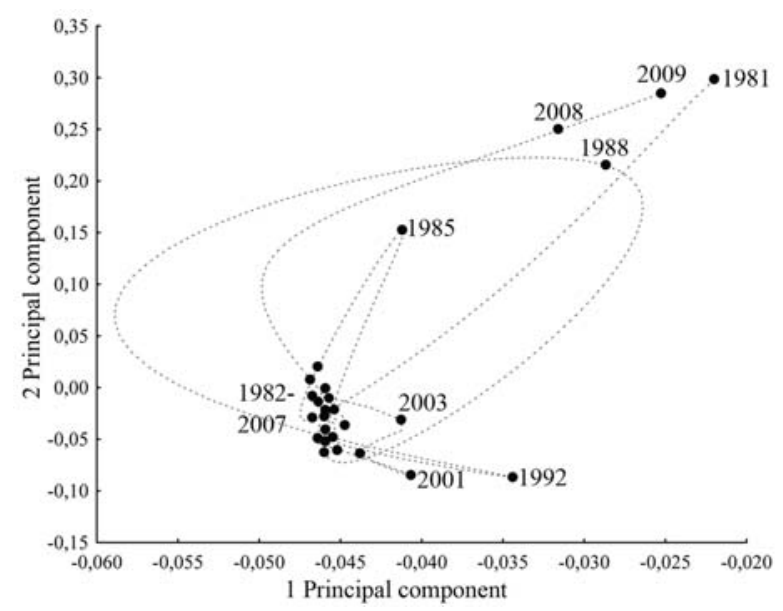

Figure 8. Long-term trajectory of the community of rodents of dark coniferous forest of East Sayan in the plane of the first two principal components.

backed vole with the population showing 25 -fold changes. Other species, placed in decreasing order of importance, include northern red-backed vole (23), eastern Asian mouse (21), root vole (19), northern birch mouse (15), field vole (12), wood lemming (7), and the bank vole (2.5). The maximum total community population size shows 12 -fold fluctuations. It suggests a direct correlation between the species numbers and the amplitude of its variations: the most numerous species have the highest long-term variability of this feature.

The absolute co-dominance of northern red-backed vole and gray red-backed vole characterizes the community as bidominant one with an unequal rank distribution of species. The northern red-backed vole is by far more abundant. It determines the number of the whole small mammals community and its change pat- tern from year to year.

A comparison of the long-term population dynamics in different species by means of cluster analysis revealed heterogeneity within the community on this basis. The patterns shown by northern red-backed vole and root vole are most similar to each other. The distribution of the northern red-backed vole, and gray redbacked vole, root vole, and field vole (Fig. 4) to various clusters indicates strength peaks shift in these species. This mutual influence of species is not a regional feature: identical divergent fluctuations in numbers are observed in these species in the boreal forests from Scandinavia to the Yakutia (Viitala, 1985; Zhigalsky, 1989; Wolpert \& Shadrina, 2002). The presence of the northern birch mouse and field vole in various clusters is determined by differences in environmental preferences of these species and different reactions to the features of hydrothermal regime of a snow-free period of a particular year. The most remote position in the dendrogram ( $\mathrm{n}<50 \%$ similarity) is taken by the rare species that do not occur in the catch every year and, as a rule, in single samples, which defines such a contrast to other community members.

The results of the conducted spectral analysis enabled defining the average duration of the harmonic vibrations of various species of rodents of dark coniferous forests of the East Sayan during the period. The longest average cycle is typical of northern red-backed vole ( 4.3 years) and gray red-backed vole ( 4.2 years). A shorter cycle is characteristic of root vole (3.7 years). The shortest cycle was observed in case of Northern birch mouse (2.1 years). In general, the values presented correspond to the data obtained for the species throughout their range (Wolpert \& Shadrina, 2002; Hörnfeldt, 2004; Korpimaki et al., 2005; Ivanter \& Kukhareva, 2008; Didorchuk, 2009). In eastern Asian mouse, field vole, wood lemming and the bank vole, the received cyclic fluctuations were not statistically significant.

For the entire community of rodents cyclical fluctuations of four years were established. This value coincides with the duration of cycles of the dominant Northern red-backed vole, and gray red-backed vole, the share of which reaches the highest values in the community throughout the period under review. The analysis of time series by means of principal component analysis showed a high degree of correlation of the first two principal components with the number of dominant species. This confirms their decisive influence on longterm dynamics and structure of the community as a whole.

The analysis of residues of spectral analysis after removal of the general harmonic component (of four years) showed that the autocorrelation function nowhere exceeds the limits of confidence intervals (Fig. 7). It means that with a 0.9 probability the autocorrelation function is absent everywhere and the whole considered time series is stationary, and does not go beyond the boundaries of a random process (white noise). Consequently, it can be argued that during the period 
Table 2. Parameters of models of multiple stepwise regression of long-term population number dynamics of 6 species of rodents of dark coniferous forests of the East Sayan depending on the given variables of environmental factors for the peri-

od from 1981 to 2009.

\begin{tabular}{|c|c|c|c|c|c|c|c|}
\hline Species & Variable & Beta & $\begin{array}{c}\text { Std. Err. of } \\
\text { Beta }\end{array}$ & B & $\begin{array}{l}\text { Std. Err. of } \\
\text { B }\end{array}$ & $\mathrm{t}$ & p-level \\
\hline \multirow{6}{*}{ M. rutilus } & Intercept & & & -45.7781 & 70.0233 & -0.6537 & 0.52153 \\
\hline & Predators* & -0.7388 & 0.1928 & -5.7866 & 1.5107 & -3.8302 & 0.00122 \\
\hline & TJ & 0.5111 & 0.1660 & 0.1017 & 0.0330 & 3.0785 & 0.00647 \\
\hline & TS & 0.4570 & 0.1818 & 0.1307 & 0.0520 & 2.5134 & 0.02169 \\
\hline & CrSeed & 0.5247 & 0.1800 & 4.3956 & 1.5081 & 2.9146 & 0.00924 \\
\hline & \multicolumn{7}{|c|}{$\begin{array}{l}\text { Regression Summary for Depended Variable: } \mathrm{R}=0.7633211 ; \\
\mathrm{R}^{2}=0.58265914 ; \text { Adjusted } \mathrm{R}^{2}=0.44354552 ; \mathrm{F}(6.18)=4.1884 ; \mathrm{p}<0.00827 \\
\text { Std. Error of estimate: } 17.949\end{array}$} \\
\hline \multirow[b]{3}{*}{ M. rufocanus } & Intercept & & & 48.2926 & 34.0397 & 1.4187 & 0.16999 \\
\hline & TS & -0.3316 & 0.2070 & -0.0399 & 0.0249 & -1.6015 & 0.12352 \\
\hline & \multicolumn{7}{|c|}{$\begin{array}{l}\text { Regression Summary for Depended Variable: } \mathrm{R}=0.3427592 ; \\
\mathrm{R}^{2}=0.11748393 \text {; Adjusted } \mathrm{R}^{2}=0.03725520 ; \mathrm{F}(2.22)=1.4644 ; \mathrm{p}<0.25290 \\
\text { Std. Error of estimate: } 9.9453\end{array}$} \\
\hline \multirow{4}{*}{ M. oеconomus } & Intercept & & & 42.4714 & 23.3608 & 1.8180 & 0.08406 \\
\hline & TS & -0.5686 & 0.1857 & -0.0455 & 0.0148 & -3.0621 & 0.00615 \\
\hline & PrY & 0.3985 & 0.1708 & 0.0282 & 0.0121 & 2.3332 & 0.03019 \\
\hline & \multicolumn{7}{|c|}{$\begin{array}{l}\text { Regression Summary for Depended Variable: } \mathrm{R}=0.6783418 ; \\
\mathrm{R}^{2}=0.46014772 ; \text { Adjusted } \mathrm{R}^{2}=0.35217726 ; \mathrm{F}(4.20)=4.2618 ; \mathrm{p}<0.01178 \\
\text { Std. Error of estimate: } 5.4274\end{array}$} \\
\hline \multirow[b]{3}{*}{ A. peninsulae } & Intercept & & & 2.03109 & 3.54666 & 0.57268 & 0.57294 \\
\hline & TM & -0.3141 & 0.19661 & -0.0113 & 0.00707 & -1.5976 & 0.12505 \\
\hline & \multicolumn{7}{|c|}{$\begin{array}{l}\text { Regression Summary for Depended Variable: } \mathrm{R}=0.4596299 ; \\
\mathrm{R}^{2}=0.2112596 ; \text { Adjusted } \mathrm{R}^{2}=0.0985824 ; \mathrm{F}(2.22)=2.2970 ; \mathrm{p}<0.5729 \\
\text { Std. Error of estimate: } 3.1995\end{array}$} \\
\hline \multirow{5}{*}{ S. betulina } & Intercept & & & 29.0333 & 9.6597 & 3.0055 & 0.00698 \\
\hline & PrS & -0.5047 & 0.1792 & -0.0197 & 0.0069 & -2.8155 & 0.01068 \\
\hline & TS & -0.4024 & 0.1902 & -0.0131 & 0.0062 & -2.1156 & 0.04711 \\
\hline & TA & 0.4090 & 0.1769 & 0.0155 & 0.0067 & 2.3124 & 0.03152 \\
\hline & \multicolumn{7}{|c|}{$\begin{array}{l}\text { Regression Summary for Depended Variable: } \mathrm{R}=0.6667914 ; \\
\mathrm{R}^{2}=0.4446107 ; \text { Adjusted } \mathrm{R}^{2}=0.3335329 ; \mathrm{F}(4.20)=4.0027 ; \mathrm{p}<0.01521 ; \\
\text { Std. Error of estimate: } 2.2388\end{array}$} \\
\hline \multirow[b]{3}{*}{ M. agrestis } & Intercept & & & -26.6046 & 14.7844 & -1.7995 & 0.08632 \\
\hline & TS & 0.5010 & 0.1987 & 0.0249 & 0.0109 & 2.2787 & 0.03324 \\
\hline & \multicolumn{7}{|c|}{$\begin{array}{l}\text { Regression Summary for Depended Variable: } \mathrm{R}=0.4963367 ; \\
\mathrm{R}^{2}=0.2463501 ; \text { Adjusted } \mathrm{R}^{2}=0.1386859 ; \mathrm{F}(3.21)=2.2881 ; \mathrm{p}<0.10803 \text {; } \\
\text { Std. Error of estimate: } 4.2964\end{array}$} \\
\hline
\end{tabular}

* Legend: temperature sum: TJ — January, TA — April, TM — May, TS — summer period; the amount of precipitation: PrS — summer period, PrY — year; CrSeed — the total yield of seeds of coniferous species; Predators — the total number of small mustelids.

under review the fluctuation of the total population number of community did not undergo significant changes beyond the boundaries of a stationary process. At the level of the 20th lag there is an increase of the correlation coefficient, which is in contact with a confidence interval and it may indicate the presence of a weakly expressed trend lasting 20-21 years.

The results of the multiple stepwise regression models allowed identifying and evaluating environmental factors that have more or less significant influence on the indicators for the various species and the entire community of rodents in general.

For the northern red-backed vole a positive effect of high-yield seed feed, warm January and a high temperature summer on the population number was identified. These factors have a direct effect on the success of breeding of the species, as well as the number of generations during the year. When seed stocks are sufficient and January temperature are rather high is under snow reproduction of northern red-backed vole in the mountains of southern Middle Siberia (Sokolov, 1979; Shubin, 1991; Vinogradov, 2007) is observed. The high temperature in summer is beneficial for the survival of the progeny of this species. The negative impact of high numbers of predators is understandable, because northern red-backed vole is the main object of their hunt due to the number and accessibility, especially in the summer.

The high sum of summer temperatures has a negative effect on gray red-backed vole, which is associated with the degree of forage reserve. The basic ration of this specific species consists of the vegetative parts of 
the berry bushes (cranberries, blueberries, and bilberry), their fruit and herbaceous plants, which in conditions of a hot and humid summer reach maximum productivity (Sokolov, 1979; Wolpert \& Shadrina, 2002).

Thus, a conclusion about the environmental characteristics of these closely related species can be made: northern red-backed vole reaches maximum strength in warm and dry years, gray red-backed vole - in cool and wet ones. These findings about backed vole are in agreement with the results of numerous studies of this group in different parts of the habitat (Sokolov, 1979; Zyryanov et al., 1997; Rexstad \& Debevec, 2006; Andreeva \& Okulova, 2009).

For root vole a positive influence of rainfalls per year is established. It determines many parameters of successful existence of this herbivorous and hygrophilous species (Gromov \& Erbaeva, 1995). A high sum of summer temperature has a negative effect on this species. It leads to increased evaporation and, hence, to adverse microclimatic conditions of root vole habitat and poor development of its forage reserve.

A negative effect of high temperatures in May on eastern asian mouse is observed. There is no account of the negative impact of this factor on rodents in Siberia. It can be assumed, that high temperatures in May determine the intensity of snowmelt in the mountain taiga, which leads to flooding of burrows and shelters of this species at the time of first spring generation cubs birth.

A positive effect of high April temperatures on northern birch mouse is shown. In years with early and warm spring northern birch mouse wake up as early as early May. In these conditions the reproduction of animals occurs in earlier and shorter periods and is more successful. The inhibitory impact on the species is caused by warm and humid summers. With such a confluence of major abiotic factors, there occurs intensive moisturizing of the underlying substrate (litter, moss, brushwood), where northern birch mouse makes its burrows and shelters. Thereby, the imperfect thermoregulation characteristic of the species leads to increased mortality of young animals (Shubin, 1991; Vinogradov, 2007; Ivanter \& Kukhareva, 2009).

The number of field vole positively depends on the amount of high summer temperatures. This more thermophilic species in high summer temperatures can give 3 generations within a snow-free period, which due to good survival of young animals leads to a sharp rise in the number of animals at the end of August.

\section{Conclusion}

The rodent community of mountain dark coniferous taiga of East Sayan includes eight species with the total numbers varying from 9.4 to 112.3 individuals per 100 $\mathrm{c} / \mathrm{d}$. Analysis of long-term population dynamics showed that fluctuation phases in the number of different species do not coincide, and therefore the structure of domination of the community is changing. The leading role belongs to two dominant species, northern red- backed vole and gray red-backed vole. These forms account for more than $50 \%$ of the community in all phases of the population numbers. The duration of cyclical changes in various species ranges from two to four years. Analysis of relationships within the rodent community has revealed pairs of species with asynchronous population dynamics, determined numerically-dependent relationships between species, making it possible to indirectly assess the degree of overlapping of ecological niches of animals.

In general, the community shows well-defined harmonic oscillations with amplitude of four years. No unidirectional irreversible changes in population in this community have been detected thus characterizing it as stable and sustainable.

Of the variety of external factors determining the population dynamics of this group of animals the most important include the total temperature of the summer period, the amount of precipitation, the yield of seeds of trees, and the pressure of predators (small mustelids). The impact of a factor on a particular type depends on the degree of its population adaptation to environmental conditions. In general, the stronger influence is cased by main climatic parameters. They determine the fluctuations in rodent numbers in the range of $31-56 \%$. The remaining load is determined by availability of food, pressure from predators, intrapopulation mechanisms and other external and internal factors, which are not identified in our study.

\section{References}

Andreeva T.A \& Okulova N.M. 2009. [Environmental preferences of forest voles] // Ekologiya. No 2. P.149-154 [in Russian].

Beklemishev V.N. 1961. [Terms and concepts necessary for quantifiable populations of ectoparasites and nikodilov] // Zoologocheskii Zhurnal. Vol.40. No.2. P. 148-158 [in Russian].

Didorchuk M.V. 2009. [Population dynamics and structure of populations of small mammals Ryazan Meshchora] // Zoologocheskii Zhurnal. Vol.88. No.1. P. 78-91 [in Russian].

Dzhiller P. 1988. [The Structure of Communities and Ecological Niche]. Moskva: Mir. 184 p. [in Russian]

Gromov I.M. \& Erbaeva M.A. 1995. [Mammals of Russia and Adjacent Territories. Lagomorphs and Rodents]. Sankt-Peterburg: Zoological Institute of the Russian Academy of Sciences. 239 pp. [in Russian]

Hörnfeldt B. 2004. Long-term decline in numbers of cyclic voles in boreal Sweden: analysis and presentation of hypotheses // Oikos. Vol.107. P.376-392.

Ivanter E.V. \& Kukhareva A.V. 2008. [To ecology of the northern birch mouse (Sicista betulina) at the northern margin of its range] // Zoologocheskii Zhurnal. Vol.87. No.4. P.476-493 [in Russian].

Korpimaki E., Norrdahl K., Huitu O. \& Klemola T. 2005. Predator-induced synchrony in population oscillations of coexisting small mammal species // Proceedings of the Royal Society of London, Series B. Vol.272. P.193-202. 
Lima M., Stenseth N.C. \& Jaksic F.M. 2002. Food web structure and climate effects on the dynamics of small mammals and owls in semi-arid Chile // Ecology Letters. Vol.5. P.273-284.

Litvinov Yu.N., Abramov S.A., Kovaleva V.Yu. \& Krivopalov A.V. 2007. [Structural and temporal organization of community rodents taiga near Lake Teletskoye (Altai)] // Ekologiya. No.6. P.444-449 [in Russian].

Livinov Yu.N. \& Pozhidaeva L.V. 2008. [Characterization of mouse-like rodent communities from the forest belt of the Altai Mountains] // Zoologocheskii Zhurnal. Vol.87. No.6. P.754-759 [in Russian].

Milstead W.B., Meserve P.L., Campanella A., Previtali M.A., Kelt D.A. 2007. Spatial ecology of small mammals in north-central Chile: role of precipitation and refuges // Journal of Mammalogy. Vol.88. No.6. P.1532-1538.

Puzachenko Yu.G. 2004. [Mathematical Methods in Ecological and Geographical Studies]. Moskva: Akademiya. 416 pp. [in Russian]

Ravkin Yu.S. \& Livanov S.G. 2008. [Factor Zoogeography: Principles, Methods and Theoretical Generalizations]. Novosibirsk: Nauka. 205 pp. [in Russian]

Rexstad E. \& Debevec E. 2006. Dynamics of small mammal populations in the Rock Creek Watershed, Denali National Park and preserve // Proceedings of the Central Alaska Park Science Symposium, September 12-14. P.69-72.

Schwartz E.A., Demin D.V. \& Zamolodchikov D.G. 1992. [Ecology of Small Mammals Communities from Tem- perate zone Forests (by the example of Valdai Upland)]. Moskva: Nauka. 127 pp. [in Russian]

Shubin N.G. 1991. [Ecology of Mammals of Southeastern West Siberia]. Novosibirsk: Nauka. 263 pp. [In Russian]

Schnurr J. L., Canham C.D., Ostfeld R.S. \& Inouye R.S. 2004. Neighborhood analyses of small-mammals dynamics: impacts on seed predation and seedling establishment // Ecology. Vol.85. No.3. P.741-755.

Sokolov G.A. 1979. [Mammals of Pine Forest of Siberia]. Novosibirsk: Nauka. 256 pp [in Russian]

Viitala J. 1985. The red vole, Clethrionomys rutilus (Pall.) as a subordinate member of the rodent community at Kilpisjarvi, Finnish Lapland // Acta Zoolgica Fennici. Vol.172. P.67-70.

Vinogradov V.V. 2007. [Small Mammals of the Kuznetsk Alatau Range]. Krasnoyarsk: KSPU. 212 pp. [in Russian]

Volpert Y.L. \& Shadrina E.G. 2002. [Small mammals of the North-East Siberia]. Novosibirsk: Nauka. 246 pp. [in Russian]

Yudin B.S., Galkina L.I. \& Potapkina A.F. 1979. [Mammals of the Altai-Sayan Mountain Country]. Novosibirsk: Nauka. 296 pp. [in Russian]

Zyryanov A.N., Knorre A.V., Andreeva E.B. \& Dolzhkovaya N.P. 1997. [Some aspects of trophic relations of small mammals in the State nature reserve "Stolby»] // V.A. Stakheev (eds.). [Scientific researches in Yenisei's Nature Reserves devoted to "predator-prey» problem]. Shushenskoye, April 1997. P. 19-22 [in Russian]. 